> Tips om medisinsk litteratur, andre bøker, filmer og elektroniske medier som bør anmeldes, sendes tidsskriftet@legeforeningen.no

\section{Viktig bok om vanskelig tema}

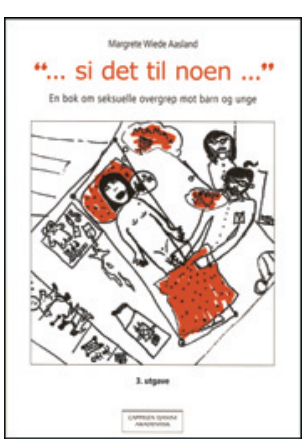

Margrete Wiede Aasland

\section{Si det til noen}

En bok om seksuelle overgrep mot barn og unge. 3. utg. 160 s, ill. Oslo: Cappelen Damm Akademisk, 2014. Pris NOK 299 ISBN 978-82-02-42103-8

Dette er en kortfattet og engasjerende bok om seksuelle overgrep som jeg vil anbefale til alle som har barn selv, eller som innimellom møter barn i jobben. For å si det som Gunnar Stålsett i forordet: «Dette er en bok til å gråte over. (...) Men dette er også en bok til å glede seg over. For med denne boken vil det ikke lenger være mulig å si: Jeg visste ikke, jeg forsto ikke, jeg trodde ikke.» Aasland er utdannet førskolelærer og har de siste tiårene jobbet som terapeut og foredragsholder innenfor området seksuelle overgrep mot barn og unge. Boken tar for seg definisjoner av begreper, lovverk, hvordan man kan snakke med barn om kropp og seksualitet, fysiske funn hos overgrepsutsatte barn, signaler barna kan gi, senskader og hva man kan gjøre når man er bekymret for et barn.

Forfatteren skriver at tegn man kan se hos barn som er utsatt for overgrep eller ikke har det godt av andre grunner, kan være mareritt, atferdsendring, seksuell utagering, konsentrasjonsvansker, spiseproblemer, selvskading, angst, depresjon, tvangslidelse, psykose og selvmordstanker. Hos noen kan man se regresjon, for eksempel at barn som kan snakke rent, begynner å snakke babyspråk, eller de begynner å tisse og bæsje på seg igjen. De kan også vise mer somatiske plager som kvalme, brekninger, hodepine, magesmerter eller «vondt i rumpa».

Aasland er kritisk til holdningen om at barn dikter opp seksuelle overgrep. «Barn lyver seg sjelden inn i vanskeligheter, barn prøver å lyve seg $u t$ av dem. For at barn skal være i stand til å lyve, må de ha en erfaring eller en kunnskap om det de lyver om.» Hun ber oss stole på magefølelsen når vi tenker at «det er noe med den ungen», skrive ned hva som gjør oss bekymret, og diskutere saken med noen som har erfaring med temaet. Aktuelle instanser å ta opp en mistanke med kan være Statens barnehus, barnevern, politi, PPT og BUP. Hun presiserer viktigheten av ikke å stille ledende spørsmål, og at eventuell etterforskning er politiets oppgave.

Det er ingen kjølig distanse til temaet i denne boken. Den er full av korte historier, sitater fra offer, tegninger og et brev. Det er mye som er vondt å lese, men det er også solskinnshistorier om de gangene ting fungerte. Man kan ikke lykkes i alle situasjoner, men man kan i alle fall vite at man gjorde det man kunne. Boken kan gjøre leseren mer observant på barn som ikke har det godt, gi mot til å ta mistanken på alvor og redskapene til å gjøre noe med det. Den er lettlest, personlig og kunnskapsrik. Seksuelle overgrep mot barn og unge er et tema alle leger bør kunne noe om, og å lese Aaslands bok er en utmerket måte å få innsikt på.

\section{Torbjørg Dahle}

Lege i spesialisering, Revmatologisk avdeling

Haukeland universitetssykehus

\section{Seksuelle overgrep mot barn i et traumeperspektiv}

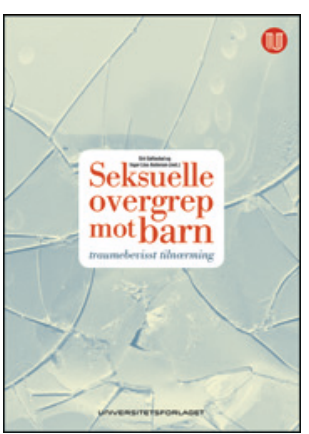

Siri Søftestad, Inger Lise Andersen, red. Seksuelle overgrep mot barn

Traumebevist tilnærming. 223 s, ill. Oslo:

Universitetsforlaget, 2014. Pris NOK 379

ISBN 978-82-15-02385-4

Seksuelle overgrep mot barn har i perioder fått helsevesenets oppmerksomhet, og senest fra midten av 1970-årene. Siden den tid har fenomenet blitt gjenstand for mye forskning, bl.a. med tanke på forekomst, symptomer og funn, rettsmedisinske forhold, potensielle senskader, behandling og seksuelle overgrep som en del av polyviktimisering. Seksuelle overgrep har både helsemessige, barnevernsfaglige og strafferettslige konsekvenser og krever en utpreget tverrfaglig tilnærming. Temaet vekker naturlig nok sterke følelser hos alle involverte, i mediene og hos «folk flest».

Målgruppen for denne boken er fagpersoner innenfor psykologi, sosialt arbeid, helsefag og pedagogikk, samt studenter innenfor disse fagene. Den tar mål av seg til å kunne leses av foreldre, privatpersoner, fagfolk fra politi og rettsvesen, beslutningstakere, politikere og andre interesserte. Den kan leses som en lærebok som spesielt legger vekt på en traumebevist forståelse av seksuelle overgrep. Bakgrunnen for traumeforståelsen er nyere hjerneforskning som har vist at alvorlige krenkelser i barndommen kan føre til funksjonelle endringer i hjernen, som igjen påvirker barnas utvikling, tilknytning, tenkemåte, evne til følelsesregulering og handlingsrepertoar. Forståelsen av dette har konsekvenser for hvordan disse barna bør bli møtt, både av omsorgspersonene og av profesjonelle aktører.

Forfatterne har bakgrunn fra fagmiljøet i Vest-Agder, der de lenge har arbeidet systematisk med å utvikle gode modeller for tverretatlig samarbeid. Nødvendigheten av tverretatlig arbeid er derfor en rød tråd gjennom hele boken, og det vises til mange eksempler på hvordan dette er utprøvd i forfatternes region. Kapittel 4 vil kanskje oppleves som spesielt interessant og relevant for leger. Her gis en kortfattet og forenklet oversikt over kunnskap om sammenhenger mellom hjernens funksjon og utvikling, og traumatiserte barns atferd og symptomer. Konsekvensene av disse sammenhengene er den andre røde tråden i boken og preger både omsorg, utredning og terapi. De som ønsker å lese seg opp på enkelttemaer, finner oppdaterte referanselister. Utvalgte referanser er i tillegg kortfattet presentert.

Utgivelsen er oversiktlig redigert i tre hovedkapitler. Mange av forfatterne bruker kasus for å illustrere viktige poeng, noe som gjør boken lettlest. Den kan trygt anbefales for kolleger som arbeider med både barn og voksne som har vært utsatt for barndomskrenkelser generelt, og seksuelle overgrep spesielt.

Arne K. Myhre

Overlege, Barne- og ungdomsklinikken og RVTS Midt

St. Olavs hospital 